DOI https://doi.org/10.18551/rjoas.2018-06.48

\title{
NORMATIVE ANALYSIS ON INVESTMENT IN MARINE SECTOR OF INDONESIA
}

\author{
Zulyadi Teuku \\ College of Public Administration, Huazhong University of Science And Technology, China \\ E-mail: teukuzulyadi@hust.edu.cn
}

\begin{abstract}
As a maritime country, Indonesia has great potential for future energy interests. However, the natural resources of the marine sector have not been properly managed so that the existing potential becomes dormant. The government needs investors to support the development of marine sector. Indonesia's marine potential value is estimated to reach Rp 3,000 trillion, but only Rp 300 trillion can be cultivated. This imbalance requires cooperation between the parties in order to build the welfare of the nation. In the implementation, investment in Indonesia still leaves the problem of the surrounding community. Like a rejection of a company that does business. In certain cases, this conflict led to the cancellation of investment business from investors. The main support from community figures such as religious and cultural figures are important considering the ethnic, cultural and religious diversity of Indonesians. This study examines the normative analysis to see the opinion of both figures in investing in marine sector. Using a qualitative approach to get more in-depth results. The results show, there is no impact either culture or religion with investment. Cultural and religious figures actually advocated the importance of investment to support the realization of the welfare of society. However, investments carried out should not violate customary law and local beliefs.
\end{abstract}

\section{KEY WORDS}

Investment policy, marine sector, normative analysis, society, welfare.

Indonesia as a developing country need resources to promote development in all fields. All available resources including natural resources, human resources and energy must be found and utilized for development purposes. Indonesia is the largest archipelago in the world with the total number reaching 13466 islands. Consists of five major islands and 30 smaller islands group. Archipelago is formed of mountains stretching from west to east, passed the Equator and located between the continents, the continent of Asia and Australia, and is surrounded by the Indian Ocean and the Pacific Ocean so that puts it in a strategic region of the world.

With thousands of islands that stretches $5,120 \mathrm{~km}$, the area of Indonesia comprises $30 \%$, while the remaining $70 \%$ is ocean. Indonesia's land area alone amounts to 1.91 million $\mathrm{km} 2$ and oceans are 6.279 million km2. Famous islands in Indonesia are Sumatra, Java, Bali, Kalimantan, Sulawesi, Maluku and Papua, then the rest are small islands. Each island has a unique culture, customs, beliefs, food, historical stories, as well as the beauty of the landscape. Indonesia has a population of more than 235 million people or fourth most populous in the world. Comprised of approximately 350 to 483 ethnic languages and cultures.

Saiful (2015) mention that together with the three big countries, namely China, India and Australia, Indonesia is considered as a major player in the region surrounding the Indian Ocean. Even many people assume that Indonesia is a determinant of progress in the region along with India. China, although not directly bordering the Indian Ocean, already see the location and the strategic role of this region. In fact, for the geopolitical interests of China has begun to build strategic interaction with the countries in the Indian Ocean. Myanmar near China politically can provide direct access from mainland China to the Indian Ocean.

In Indonesia, there are 13 provinces and 70 regencies / cities bordering the Indian Ocean, including Aceh. In contrast to other provinces in the southern part of Sumatra were faced with vast expanse of ocean, Aceh is the ocean gateway to countries, peoples, cultures and civilizations in the Indian Ocean region. 


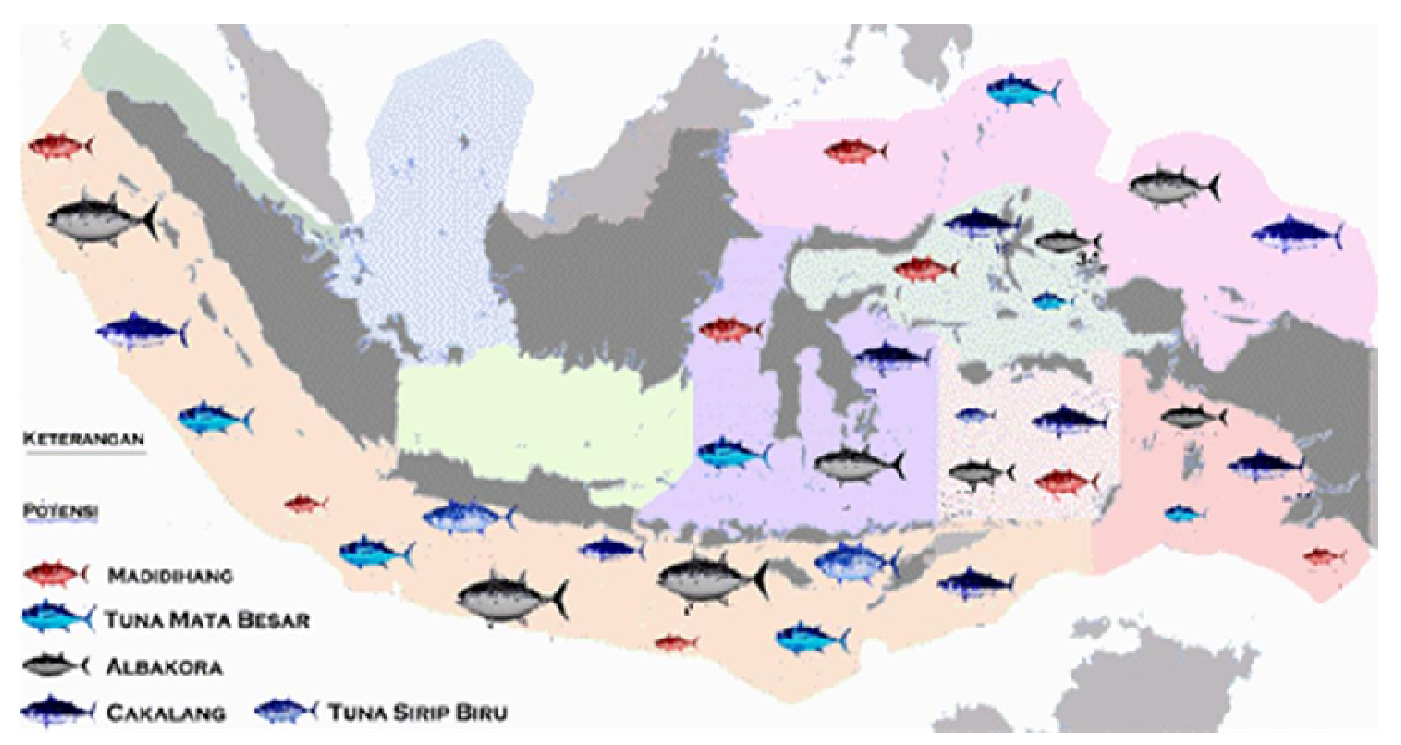

Figure 1 - Map of marine and fishery potential of Indonesia

The formation of the Ministry of Marine and Fisheries was basically a challenge, and an opportunity for the development of marine and fisheries sector in Indonesia. That is, how the ministry is putting marine and fisheries sector as one of the leading sectors that can deliver the Indonesian nation out of the prolonged economic crisis. At least there are some basic reasons underlying it. (http://kkp.go.id/sejarah (2016).

First, Indonesia is an archipelago with 17,508 islands and a number of $81,000 \mathrm{~km}$ coastline not only as the largest archipelago in the world but also save natural resources wealth of marine and large have not been used optimally.

Second, for decades, the development orientation of the country has been towards more land use, resulting in land resources depleted. It is therefore natural that marine resources and fishery should be developed for future.

Thirdly, linked to population growth and increased human awareness of the importance of fisheries and marine products for the health and human intelligence, it is believed to still be able to improve fisheries and marine products in the future. Fourth, coastal areas and oceans are dynamic not only have the resource potential, but also has the potential for development of a variety of development activities that are extraction such as industrial, residential, conservation, etc.

The economic potential of Indonesian marine and marine-related activities, such as fisheries, sea transport, maritime industry and marine tourism has increased significantly. In Indonesia, the new sea-based industries have been growing rapidly and will continue to grow in the future. It offers enormous economic opportunities, especially for investors and banks. The potential value of marine economy is estimated to reach $\mathrm{Rp} \mathrm{3,000} \mathrm{trillion} \mathrm{per} \mathrm{year,} \mathrm{where}$ the value of economic activity in 2013 only around Rp 291.8 trillion. These values reflect that marine economic potential of Indonesia as a maritime state has not been optimally, even almost untouched investors and banks

The economic opportunities derived marine potential of seabed mineral that is currently entering the initial exploration stage. A series of studies have been conducted to explore the mineral and sea water. Where seventy percent of the 60 potential sites for oil and gas deposits located in the sea world. In addition, new energy and renewable energy such as offshore wind, tides and waves, and marine biotechnology are also plentiful and still need to be explored and developed in the future.

In addition, the marine transportation sector provides huge investment opportunities in infrastructure, shipping and shipbuilding, ports, docking, and other activities, such as logistics and trade. Since 2006, Indonesia has become one of the leading ship of 22 countries in the world, which has built 126 ships, or about 586.00 Gross Tons and investment opportunities 
are still open. Among the investment opportunities related marine sector is a marine tourism. Indonesia with $104,000 \mathrm{~km}$ coastline and thousands of islands have marine tourism potential is very large.

There are eleven sectors of the marine economy can be optimized, namely: capture fisheries, aquaculture, fishery product processing industry, industrial bio-technology marine, mining and energy, marine tourism, mangrove forests, sea transportation, resource area small islands, industry and maritime services, as well as the natural resources of nonconventional.

The total economic value of the eleven sectors of the marine economy is estimated to reach more than Rp. 3.000 trillion / year and can provide employment to over 40 million people. From all this potential, only Rp. 291.8 trillion alone, or less than 10 percent that has been well explored. If it is managed properly, many people believe that this potential can make a major contribution to the welfare and prosperity of the people of Indonesia.

The reality today is really ironic. Coastal communities that are dependent on the maritime sector is precisely the poorest people. Based on data from the Central Statistics Agency (BPS) in 2008 stated that the poor people in Indonesia reached 34.96 million people and 63.47 percent of them are people who live in coastal areas and rural areas.

Table 1 - The export volume of Indonesia fisheries product by country of destination 2010-2014

\begin{tabular}{|c|c|c|c|c|c|c|c|}
\hline \multirow{2}{*}{$\begin{array}{l}\text { Destinatio } \\
n\end{array}$} & \multicolumn{5}{|l|}{ Year } & \multicolumn{2}{|c|}{ Increasing average (\%) } \\
\hline & 2010 & 2011 & 2012 & 2013 & 2014 & $2010-2014$ & $\begin{array}{l}2013- \\
2014\end{array}$ \\
\hline $\begin{array}{l}\text { Total } \\
\text { (unit; ton) }\end{array}$ & $\begin{array}{l}1.103 .5 \\
76\end{array}$ & $\begin{array}{l}1.159 .34 \\
9\end{array}$ & $\begin{array}{l}1.229 .11 \\
4\end{array}$ & $\begin{array}{l}1.258 .18 \\
0\end{array}$ & $\begin{array}{l}1.274 .98 \\
2\end{array}$ & 3.69 & 1,34 \\
\hline PRC & $\begin{array}{l}213.05 \\
5\end{array}$ & 242.397 & 295.486 & 336.648 & 344.374 & 12,97 & 2,29 \\
\hline Thailand & $\begin{array}{l}193.72 \\
3\end{array}$ & 160.471 & 216.407 & 227.947 & 198.871 & 2,57 & $-12,76$ \\
\hline USA & $\begin{array}{l}127.79 \\
2\end{array}$ & 126.931 & 133.476 & 136.847 & 168.017 & 7,45 & 22,78 \\
\hline Japan & $\begin{array}{l}126.51 \\
4\end{array}$ & 123.830 & 118.732 & 115.594 & 108.847 & $-3,68$ & $-5,84$ \\
\hline Malaysia & 53.353 & 54.885 & 53.187 & 55.059 & 58.057 & 2,19 & 5,45 \\
\hline Singapore & 44.751 & 65.926 & 42.840 & 42.332 & 39.388 & 1,04 & $-6,96$ \\
\hline $\begin{array}{ll}\text { Rep. } & \text { Of } \\
\text { Korea } & \\
\end{array}$ & 31.543 & 32.662 & 30.527 & 26.016 & 28.166 & $-2,38$ & 8,26 \\
\hline Italy & 11.734 & 15.365 & 11.318 & 13.236 & 18.565 & 15,45 & 40,27 \\
\hline $\begin{array}{l}\text { United } \\
\text { kingdom }\end{array}$ & 11.401 & 11.454 & 13.334 & 16.986 & 17.329 & 11,57 & 2,02 \\
\hline Others & $\begin{array}{l}250.52 \\
2\end{array}$ & 294.284 & 276.082 & 256.363 & 259.778 & 1,37 & 1,33 \\
\hline
\end{tabular}

Source: Marine and fisheries in figures, 2015.

"Axis of World Maritime" This is a serious challenge Jokowi government now. Moving into a maritime continental orientation is not an easy issue because it requires development in various sectors and scales. In reconstructing the Indonesian maritime country includes not only economic, but also the environment, defense and security, science and technology, socio-cultural, and institutional. In the economic sector alone, according to some circles, the government should at least have to immediately develop maritime connectivity, revitalizing marine economic sectors that have so far, in addition to develop other sectors of the marine economy's new.

People's demand for the fulfillment of public facilities continued to increase both in quantity and quality. The government will be difficult to compensate if only using traditional methods because the provision would be constrained by financial resources, technology and 
even managerial. One alternative to overcome the obstacles is investment policy for marine sector. This concept has been applied in various countries and regions with different benefits and drawbacks that exist in it. For the area, this is an alternative to accelerate infrastructure development and optimization of asset management / wealth of the area as well as potential sources of local revenue. Commitment of policy makers and various technical considerations will determine the success of its implementation in the area.

Supriatna (2008), revealed that since autonomy is rolling, there is overlapping authority and regulation between the Central Government and the regions, between one sector and other sectors, between certain public and community needs in one location. A wealth of resources utilization context in Indonesia, is still often give rise to differences of interest between Government, the public sector, and private sector. The cases often occur and can not be avoided, when in the area found the quarry material (such as oil, coal, etc.) that are very profitable. The conflict between the Central Government with local Government can arise due to different interests.

This study aimed to regulatory evaluation and normative analysis of investment in marine sector in Indonesia.

Maritime Affairs And Fisheries Policy Forward. Sutardjo (2014) reported the development of a national marine policy has the objective to strengthen the sovereignty and unity of the Republic of Indonesia as an archipelagic country. Developing a sustainable marine management systems to governance and the space utilization of marine resources integrated with the concept of the island nation. Develop a system of marine resource management and marine services to boost economic growth and equity towards more robust maritime nation. Improving the welfare of the community.

National marine policy needs to be based on some principles, namely base Islands and Welfare State: Development based sea island nation and welfare. Most of the area in the form of sea which brings together thousands of islands as a whole territory of the Republic of Indonesia. Sustainability, balance the economic, social, cultural and environmental conservation to meet the needs of today and the future. One Unity Ecosystem, An archipelago of Indonesia should be seen as a whole marine ecosystems, land, and atmosphere.

Multi Use Marine and Integrated Management, Utilization of marine diversity of natural resources grow the diversity of economic activity, trade, social, cultural, environmental, defense and security in the marine and coastal management system requires Seafood. Good Ocean Governance, sustainability, based knowledge, accountability, participation, coordination, decentralization, justice, the interests of national and international attention to the relationship.

Implementation of these policies include 3 approaches consist of:

a. Application of the principles Seafood Good Governance (good ocean governance): ie towards sustainable development of marine resources through the development of integrated marine utilization system (integrated sea use management),

b. Development of Economic Zone Blue: the economic region as a center for environmentally friendly economic growth,

c. Development of Investment and Business Model Blue Economy: the system of investment and businesses that use the principles of sustainability, resource efficiency, do not leave any form of waste, and social concern, which is to increase income and employment more widely.

The growth of construction and industrial projects in international public works agreements has significantly increased in recent decades, particularly in Asean and Indonesian. The phenomenon of public -private partnership (PPP), though far from being novel, is still being actively developed, with many conceptual issues remaining subject to discussion

So is the case with Indonesia, as a developing country in need of a big budget to build infrastructure in various fields. These budgets needs can not be met by the government. (Zapratina, Zveverev, Rodina, 2015). In cooperation must of course be done with the understanding that is protected by law. The model law defines PPP as "mutually beneficial 
cooperation of public and private partners which is legally documented for a specified period of time, based on their pooling of resources (including monetary funds and other property, professional and other knowledge, expertise, and skill) and allocation of risk among them (including financing and constraction risks, risks associated with ensuring of accessibility of demand for a public-private partnership object or respective public services as well as other related risks) in order to achieve govermental, municipa or other public interest goals within the area public interests and control".

In practise, these ideas were mainly supported by the public-sector reform movement known as New Public Management (NPM). That intensively supported the decentralisation of goverment and the privatisation of public service which should be handed over to private companies. (Kitsos, 2015). The NPM strongly favors basing public administrative decisions on market criteria. In genaral, NPM enbraces enterpreneurial orgaanizations, considers customers satisfaction of key importance, and seeks to set up perfomance based organizations to mirror private corporations in performing goverment operation.

According to Rosenbloom (2013), New public management (NPM) is a public management concepts that apply to the private sector working practices of the public sector to create efficiency and effectiveness of government performance that will create welfare society (public welfare). One of the important theoretical source of New Public Management is humanism organization. Over the last thirty years, the theory of public administration have joined in the other disciplines in showing the traditional hierarchical approach to social organization that strict in their view of human behavior, and they have joined in the criticism of bureaucracy and seek alternative approaches to management and organization. Collectively, these approaches have attempted to fashion a public organization less dominated by issues of power and control as well as more attention to the needs and concerns of internal and external constituents.

Ismail (2011) argues that the great influence of cultural and legal globalisation played a fundamental role in the liberalisation, modernisation and internationalisation of the administrative contracts theory. Globalisation, after all, represent not only the flow of capital, commodities, individuals and other tangibles, but also intangibel values, such as cultural and legal influence.

Dwiyanto (2006) state that the success of the development efforts of Government and private partnership in public services is determined by many factors, including: (1) a partnership that emphasizes on coproduction and co-provision will only be effective if followed by a change in attitude and orientation of bureaucratic government officials; (2) the Government needs to continue to develop and provide facilities for the development of the private sector; (3) the Government needs to reduce his involvement in public service operations if the private sector organizations volunteer and business companies can already do it; (4) the transfer to the private sector the role of Government should be done in transparent and open; and (5) the grant of power to the private sector need to be followed by improvements to the effectiveness of the political and bureaucratic with control.

\section{METHODS OF RESEARCH}

This research used the qualitative approach, since, first, the study rests on the power of narrative or explanation regarding the verbal description of the invesment policy, second, researchers tried to do some research for what it is. That is, element manipulation be avoided wherever possible. Third, inductive analysis used because the method of data retrieval done through in-depth interviews and questions submitted to its open, where the interviewee is free to answer questions submitted in accordance with the definition which he saw. The third reason above is reinforced by an explanation by Patton (1990) that the ideal method, a strategy that is typical of qualitative consists of three parts: (1) the qualitative data, (2) investigation of naturalistic and (3) analysis of the content of the inductive basis or based on the case. 
The expectations of researchers through the research approach, information can be obtained about existing phenomena and facts about the implementation process of the implementation of Government and private partnerships in maritime sector.

Neuman (2013) says that for qualitative research, the selection of the sample (informants) is more appropriately done deliberately (purposive sampling).

To obtain accurate information in this study then the researchers using the technique of sampling aims (purposive sampling) because the informant taken knowing and experienced in private-Government partnership program marine sector of Indonesia.

In this study, the informants were selected based on criteria that have been established, including: a) individual who understands and is directly involvedon investment policy in marine Indonesia., b) individuals who understand, coupled and involved indirectly on investment policy in marine Indonesia

Based on these criteria then the selected distinguished informant over two large categories, which are: a) groups directly involved, Government (decission maker and official), investor b) groups that are involved indirectly, including from NGOs, local custom actor and fishers as well as the community.

In-depth interviews is a way used by the researcher/interviewer for the purpose of getting information establishment orally a face-to-face interviews with respondents. (Malo \& Trisnoningtias, 1992:124-125). The purpose of the interview is to obtain primary data obtained directly from the informant by asking questions that aim to dig in and get information relating to the research issues.

\section{RESULTS AND DISCUSSION}

Raihanah (2016) said that there are four important things to note, in order to attract and bring in Indonesian fishery investors. First, the availability of fish resources is very important in building the fishery industry, because fish is the main raw material that must be available continuously.

Second, facilities and infrastructure. Ocean fishery ports serve large capacity ships, so the fish are landed fish for industrial raw materials for export purposes. If this facility is adequate, fish resources are still maintained and sustainable then investors will come to invest. Fisheries commodity is a promising business opportunity, world market demand is very high for the fishery sector. Moreover, some areas of fisheries management in the country have shown excessive catch.

Third, clear and easy regulation of fisheries and eliminate permit requirements that hamper the investment climate, but it is necessary to create quick and easy services in line with central government policies. Cooperation between agencies should also be in line so as not to make the impression difficult.

Fourth, security. The security guarantee for investors in investing is highly deserved and should be realized in any situation. In the discussion of this research, security assurance is related to the context of a plural Indonesian society. As a large country with diverse ethnicities, different cultures and local wisdom it is very important to pay attention and maintain a harmonious relationship between the investment actors and the surrounding community.

Table 2 - The potency of aquaculture area and usage level in indonesia, 2014

\begin{tabular}{|c|l|c|c|c|c|}
\hline No & Type of aquaculture & Potency & Usage & Developing oppurtunity & $\begin{array}{c}\text { Percentage of usage } \\
\text { aquaculture area }\end{array}$ \\
\hline 1 & Brackishwater pond & 2.964 .331 & 667.083 & 2.297 .248 & 22,50 \\
\hline 2 & Freshwater pond & 541.100 & 161.387 & 379.713 & 29.83 \\
\hline 3 & Inland operator & 158.125 & 1.707 & 156.418 & 1,08 \\
\hline 4 & Rice fish & 1.536 .289 & 142.122 & 1.394 .167 & 9,25 \\
\hline 5 & Mariculture & 12.123 .383 & 281.474 & 11.841 .909 & 2,32 \\
\hline
\end{tabular}

Source: Marine and fisheries in figures, 2015. 
The Indonesian government recognizes and places adat law as one of the sources of formal law. The custom of the local people is called an unwritten law. Likewise the people, called indigenous peoples because they still run these habits so that the norms in every line of life. Mansur, T. M. (2016) defines adat as a rule or rule made by man who has been practiced in the past in the form of deeds, behavior and speech to regulate the order of community members. The emphasis on the dimension has always been a sign that the practice is still practiced until it is repeatedly practiced by the people.

Furthermore, Mansur, T. M. (2016) states that adat is a custom, tradition, human behavior that is consistently followed by society in order to regulate their order to order and orderly lives. This order encompasses all aspects of people's lives, including jobs and professions. Farmers, fishermen, traders are the professions of society that become the sphere of customary order.

In practice, the existence of adat law is very inherent with religious teachings, especially Islamic religion. Customary law and religious law do not touch each other because some customary law is absorbed from religious teachings. If there is a difference, then religious law is adhered to and adhered to by the people. In practice, adat leaders and religious leaders are people who understand the customs and at the same time a strong religious understanding so as to explain and foster society based on custom and religion.

Customary law and religion that develops in Indonesian society also alludes to modern problems, such as investment, corporations and macroeconomics for the benefit of the state and nation. The economic growth of the country is very important for the sustainability of its people, therefore the indigenous people and religion support the existence of investment, both foreign investment and domestic investment. For the record, the presence of investors and businesses does not undermine and disrupt the rights of communities protected by the state and local customs.

So far, if the existence of the investors actually have an impact on the addition of local people's income, job opportunities and economic wheels berputaranya. In this context, traditional and religious leaders strongly support every effort undertaken by the entrepreneur. Based on an interview with Rahman Kaoy (2017), one of Aceh's religious and cultural figures said that the migrant community needs to adjust its situation with the people of Aceh, the prayer should not be disturbed. See what conditions are there. Not the aceh people do not accept foreigners. The assumption of the aceh people is that all human beings are siblings of the offspring of the prophet adam. The people of Aceh believe in the truth of the Qur'an, coming for brothers are allowed. Not interrupting, helping each other, doing good, brainstorming. Accepted as long as it does not interfere with religion, the state of society, although different religion is not the problem of origin does not disturb.

\begin{tabular}{|c|c|c|c|c|c|c|c|c|c|c|c|c|c|c|c|c|c|}
\hline Capital Status & 2000 & 2001 & 2002 & 2003 & 2004 & 2005 & 2006 & 2007 & 2008 & 2009 & 2010 & 2011 & 2012 & 2013 & 2014 & 2015 & 2016 \\
\hline Foreign investment & 16 & 1 & 7 & : & 11 & 6 & 4 & 7 & 7 & $\mathbf{1}$ & g & $\mathbf{1}$ & 9 & 11 & $\mathbf{B}$ & 13 & 11 \\
\hline Domestic investment & 52 & 52 & 11 & 17 & $\mathbf{n}$ & 1 & $\mathbf{3}$ & 4 & 11 & 17 & $\mathbf{y}$ & $\mathbf{x}$ & 32 & 0 & $\mathbf{4}$ & 50 & B \\
\hline other & $\pi$ & $\mathbf{H}$ & 9 & 9 & 19 & $\mathbf{E}$ & 2 & $\mathbf{n}$ & $\mathbf{5}$ & $\mathbf{2}$ & $\mathbf{z}$ & $\mathbf{2}$ & $\mathbf{n}$ & $\mathbf{A}$ & $\theta$ & $\mathbf{z}$ & 19 \\
\hline total & $\mathbf{1 0}$ & $\mathbf{m}$ & 30 & 34 & 51 & $\mathbf{1 1}$ & $\boldsymbol{Z}$ & $\mathbf{9}$ & $\mathbf{4}$ & 8 & 또 & Q2 & $\mathbf{H}$ & e & BS & Bi & 5 \\
\hline
\end{tabular}

Figure 2 - number of fishing companies by capital status, 2000-2016

Investors are allowed to establish companies and run their business in various places in the territory of the Republic of Indonesia as long as they comply with the rules set by the government. The rules are not only related to the business sector, but also the rules of custom and religion that apply in the business area.

Alyasa (2017) also gave a similar answer, that between religious teachings are not contrary to business actors. Instead, it advocates for adherents to invest. I think there is no contradiction between Islamic teachings and investment. Because Islam itself teaches to prosper the earth. To be the Caliph on earth. Then, in the history of the Islamic Ummah itself called investment and trade it is advisable. But there are things that must be taken care of, 
not violating some principle of prohibition. Like not doing the practice of usury, not exploitative. No monopoly, that's all.

Islamic syariat does not hamper investment, If there is any incident that happened it is not because of Shari'a. There are other factors, things that could be poor communication, can be exploitative with the surrounding community. It is possible to relate to social and economic, not religious.

Syahrizal (2017) states that the Government can guarantee the existence of investors. There is a presumption of people as if there are obstacles from the side of sharia, there is no it. The most important thing is to communicate well, with the government and society. Not only is he aceh, everywhere is like that. The prejudice is not grounded. Indeed there is a lack of us that, the lack of building communication about the existence of sharia in aceh.

There was no effort from the people who came exclusively to discourage the existence of investment. Precisely the main problem of our society today is the economic problem. There is no certainty what the community is working for. So many wild issues are growing in the community. It is as if there is a society that inhibits the existence of investment in aceh.

Investment in Indonesia is very large potential, but must consider the social, cultural and environmental awareness of the community. So important in a company's feasibility study, in the study should also be able to map the existence of environmental factors both social and other.

The government strongly supports the existence of investment, as disclosed by Zulkarnaen (2017) The principle of government is very open with investors, from wherever please come. But what needs to be maintained is the existence of local culture. Administration is facilitated by, if necessary initiated business forums with various countries. Including china and other countries in the world.

Allows to make a direct connection between the government and China, although managed by the region and the country. The potential in aceh is enormous, all we have to do is build communication with the outside world, especially with the international market.

Governor of Aceh is very focused with the presence of investors, which must be considered is the action after the visit. Do not just visit and build cooperation. If there is a follow-up action, directly processed with principle permission.

In carrying out investment in the marine sector is very important to pay attention to the existence of fishermen, especially fishermen adjacent to the investment location. Muttaqin (2017) states that Panglima laot protects the existence of fishermen, coordinates with the government by providing input to government policy. The presence of investors should not hurt the small fishermen. The principle, please investors profit, small fishermen also have to benefit. In some cases, violations committed by large investors, such as those related to catch areas. In the rule, boats that have 30 GT engine capacity should not catch fish below 4 miles. They should go to 12 miles. It is arranged in fisheries.

Local wisdom is to save the existence of nature, investment is allowed but note the environmental, social, natural and other environmental. Syahrizal (2017) also revealed the same thing that there should be no aggrieved parties, budgeting out of contract if the Shari'a runs. Investment must pay attention to the existence of environment, CSR. Treat the environment as it should. If you really do invest, go ahead.

The government will help and protest and encourage to help your investment. The government will also assist the existence of entrepreneurs, whether the community gets the benefits of employment, the government gets revenue and business actors also gain profit. Now that must be considered is comfort and stability. Actually, there should be no fear. Society also need not be feared. Unless we discriminate, treat people according to their qualifications.

The religion of Islam adopted by the majority of Indonesian people and the culture of the local community is not at all contrary to the investment efforts, be it domestic or foreign investment. The presence of investors is actually able to increase the economic turn around the community. Abizal (2017) mentions, in Islamic teachings, investment is encouraged. The wealth is the most from the source of trade, including the investment. Investments are fine. Someone is giving capital to a place / country. For example, in a plantation there are those 
who provide land and some give their services. But in the corridor that does not deviate from the provisions of God, for example investment related to usury.

Rusmilyansari (2010) says that there are five conflict-causing indicators that significantly contribute to conflict-causing factors. These indicators are: (i) competence in resource utilization (ii) the presence of opposing parties (iii) economic conditions of the community (iv) many of the parties involved and (v) cultural and customary backgrounds. So the factor that causes the conflict to be considered is the interaction of the five indicators.

The existence of investors allows the emergence of conflicts between groups in society if not regulated as possible. Law Number 25 Year 2007 on Capital Investment states one article governing CSR. Article 15 letter b reads as follows: "Every investor shall be obliged: to carry out corporate social responsibility." Elucidation of Article 15 letters adds that what is meant by "corporate social responsibility" is the responsibility attached to each investment company to keep creating a harmonious relationship, balanced, and in accordance with the environment, values, norms, and culture of local communities.

While Law Number 13 Year 2011 on the Handling of Poor states, there are at least two articles that pertain to CSR in Law no. 13 Year 2011. First, Article 36 paragraph (1) letter c which states that one of the funding sources in handling the poor, is the funds set aside from the company. This provision is affirmed by Article 36 paragraph (2) which reads, "The funds set aside from the company company as referred to in paragraph (1) letter $c$ shall be used as much as possible for the handling of the poor."

In addition, there is also Article 41 which uses the term community development. Article 41 paragraph (3) explains that business actors participate in providing community development funds as a manifestation of social responsibility for the handling of the poor.

Both of these rules firmly state the investors to carry out the obligation to maintain the relationship between the company and the community and the environment. Religious groups, cultures and companies alike carry out the task of maintaining diversity and effort. this obligation applies to domestic and foreign capital investors, if not done can be subject to administrative sanctions in the form of: written warning, restrictions on business activities, freezing of business activities and / or investment facilities; or revocation of business activities and / or investment facilities.

\section{CONCLUSION}

Maritime potential is an investment opportunity for the future of the Indonesian nation. To manage it, it takes a lot of capital both coming from local and foreign investors. The existence of investors should not damage the culture, social, religion and environment of the surrounding community. In the view of religious and cultural figures there is no persolan between investment and socio cultural life of society. If there is any turmoil between the company and the surrounding community is triggered due to unfulfilled licensing and rights issues.

On this basis, it is important for governments, investors to delve deeper into the rules that apply to run businesses in Indonesia. After that, it needs a joint supervision involving the community that the rules are run by the government itself and the investors.

\section{CONFILICT OF INTERESTS}

Author celarly declare that they have no competing interests.

\section{REFERENCES}

1. Dwiyanto, A. (2006). Reform of the public bureaucracy in Indonesia. Gadjah Mada University Press.

2. http://kkp.go.id/sejarah/. Retrieved November 24, 2016. 
3. Ismail, M. A. (2011). International Infrastructure Agreements and PPPs in Developing Countries: Substantive Principles with Special Reference to Arab and Latin American Countries. Eur. Pub. Private Partnership L. Rev., 147.

4. Ismayanti. (2015). Marine and fisheries in figure 2015, the center for data, statistics and information.

5. Malo, Manasse and Sri Trisnoningtias. (1992) Community research methods. Depok: Inter University Center of Social Sciences University of Indonesia. Public management in the perspective of new public management, UIN Kalijaga, 2013

6. Mansur, T. M. (2016). The position of the Adat Court after the Law on the Governing of Aceh. Kanun: Journal of Legal Studies, 18 (2), 209-218.

7. Neuman, W. L. (2013). Social research methods: Qualitative and quantitative approaches. Pearson education.

8. Patton, M. Q. (1990). Qualitative evaluation and research methods. SAGE Publications.

9. Raihanah (2016) http://aceh.tribunnews.com/2016/05/04/mencari-investor-perikansulitankah

10. Rosenbloom, D. H., \& Goldman, D. D. (1993). Public administration: Understanding management, politics, and law in the public sector. New York: McGraw-Hill.

11. Rusmilyansari, R., Wiryawan, B., Haluan, J., \& Simbolon, D. (2010). Capture conflictbased fisheries resource management model. Marine Fisheries: Journal of Marine Fisheries Technology and Management, 1 (2), 65-75.

12. Saiful M, (2015) http://aceh.tribunnews.com/merekonstruksi-budaya-maritim,

13. Sharif Cicip Sutardjo. (2014), Marine and Fisheries Development Policy Ahead. Journal. Policy. Fishing. Ind. Vol.6 No.1

14. Supriatna, J. (2008). Preserving Nature Indonesia. Yayasan Obor Indonesia.

15. Zapatrina, I., Zverev, A., \& Rodina, A. (2015). Harmonization of public-private partnership legislation: regional and international context of the Model Law on Public-Private Partnerships for the CIS Countries. Eur. Procurement \& Pub. Private Partnership L. Rev., $10,3$. 